\title{
Improving the Tribological and Mechanical Properties of an Aluminium Alloy by Deposition of AISiN and AlCrSiN Coatings
}

Totka Bakalova ${ }^{1}$, Nikolay Petkov ${ }^{2}$, Hristo Bahchedzhiev², Pavel Kejzlar ${ }^{1}$, Petr Louda ${ }^{3}$, Marián Ďurák ${ }^{3}$

${ }^{1}$ Institute for Nanomaterials, Advanced Technologies and Innovation, Technical University of Liberec, Studentska 2, 461 17 Liberec, Czech Republic. E-mail: totka.bakalova@tul.cz, pavel.kejzlar@tul.cz

${ }^{2}$ Central Laboratory of Applied Physics, Bulgarian Academy of Sciences, 61, St. Peterburg Blvd. 4000 Plovdiv, Bulgaria. E-mail: petkovnik@gmail.com, hristo_bah@abv.bg

${ }^{3}$ Faculty of Mechanical Engineering, Department of Material Science, Technical University of Liberec, Studentska 2, 461 17 Liberec, Czech Republic. E-mail: petr.louda@tul.cz, marian.durak@tul.cz

This paper presents an improvement to the mechanical and tribological properties of aluminium alloys. AISiN and AlCrSiN coatings (with different $\mathrm{Cr}$ content) were deposited on substrates of Al-Cu-Mg alloy by the cathodic arc evaporation method at $400^{\circ} \mathrm{C}$. Surface morphology and chemical composition were estimated by a scanning electron microscope equipped with an energy dispersive spectrometer and mechanical profilometer. The increasing chromium content in the coating led to an increase in the coating hardness. The tribological behaviour of the coated and uncoated Al-Cu-Mg alloy samples was examined using the "Ball-on-Disk" method (ASTM G99-95) at a load of $10 \mathrm{~N}$ using $\mathrm{Al}_{2} \mathrm{O}_{3}$ ball as a counterpart.

Keywords: AlSiN thin films; Cathodic arc deposition; Aluminium substrate, Coefficient of friction

\section{Acknowledgement}

This paper was supported by the project LO1201, through the financial support of the Ministry of Education, Youth and Sports in the framework of the targeted support of the "National Programme for Sustainability I" and the OPR\&DI project “Centre for Nanomaterials, Advanced Technologies and Innovation” registration number CZ.1.05/2.1.00/01.0005. We would also like to thank Craig Hampson for his help with English language correction.

\section{References}

[1] REIS, D. A. P., COUTO, A. A., DOMINGUES JR. N. I., HIRSCHMANN, A. C. O., ZEPKA, S., MOURA NETO, C. (2012). Effect of Artificial Aging on the Mechanical Properties of an Aerospace Aluminium Alloy 2024, pp 193198, Defect and Diffusion Forum Vols. 326-328.

[2] LIAO, J.X., XIA, L.F., SUN, M.R., LIU, W.M., XU, T., XUE, Q.J. (2004). The structure and tribological properties of gradient layers prepared by plasma-based ion implantation on 2024 Al alloy, pp. 392-399, J. Phys. D: Appl. Phys. 37.

[3] LIFANG, X., ZHAOHUI, Y., JIAXUAN, L. (2004). Effects of intermediate layers on the tribological behavior of DLC coated 2024 aluminum alloy, pp. 599-605, Wear 257.

[4] LIAO, J. X., XIA, L. F., SUN, M. R., SUN, Y., LIU, W. M., XU, T., XUE, Q. J. (2004). Tribological behavior of gradient modified layer on 2024 aluminum alloy modified by plasma-based ion implantation, pp. 840-845, Wear 256.

[5] LIAO, J. X., XIA, L. F., SUN, M. R., LIU, W. M., XU, T., XUE, Q. J. (2004). The tribological properties of a gradient layer prepared by plasma-based ion implantation on 2024 aluminum alloy, pp. 157-164, Surface and Coatings Technology 183.

[6] LIAO, J. X., XIA, L. F., SUN, M. R., LIU, W. M., XU, T., YANG, C.R., CHEN, H.W., FU, C.L., LENG, W. J. (2005). Structural characteristics of 2024 aluminum alloy plasma-based ion implanted with nitrogen then titanium, pp. 71-76, Applied Surface Science 240.

[7] STAIA, M. H., PUCHI CABRERA, E.S., IOST, A., ZAIRI, A., BELAYER, S., VAN GORP, A. (2015). Tribological response of AA 2024-T3 aluminium alloy coated with a DLC duplex coating, pp.74-87, Tribology International - Vol. 85.

[8] PETKOV, N., BAKAlOVA, T., CHOlAKOVA, T., BAHCHEDZHIEV, Hr., LOUDA, P., RYŠÁNEK, P., KORMUNDA, M., ČAPKOVÁ, P., KEJZLAR, P. (2017). Study of Surface Morphology, Structure, Mechanical and Tribological Properties of AlSiN coating obtained by Cathodic arc deposition method, Superlattices and Microstructures, Available online 11 May 2017, https://doi.org/10.1016/j.spmi.2017.05.022.

[9] BAKALOVA, T., LOUDA, P., VOLESKÝ, L., ANDRŠOVÁ, Z. (2014). The Use of Optical Microscopy to Evaluate the Tribological Properties. In: Manufacturing Technology, Vol. 14, No. 2, pp. 256-261. ISSN 1213-2489.

[10] BAKALOVA, T., PETKOV, N., BAHCHEDZHIEV, Hr., KEJZLAR, P., LOUDA, P. (2016). Comparison of mechanical and tribological properties of TiCN and CrCN coatings deposited by CAD, In: Manufacturing Technology, Vol. 16, No. 5, pp. 854-858. ISSN 1213-2489. 